\title{
Roads affect the spatial structure of butterfly communities in grassland patches
}

\author{
Piotr Skórka Corresp., 1 , Magdalena Lenda ${ }^{1,2}$, Dawid Moroń ${ }^{3}$ \\ 1 Institute of Nature Conservation, Polish Academy of Sciences, Kraków, Poland \\ 2 School of Biological Sciences, The University of Queensland, Brisbane, Australia \\ 3 Institute of Systematics and Evolution of Animals, Polish Academy of Sciences, Kraków, Poland \\ Corresponding Author: Piotr Skórka \\ Email address: skorasp@gmail.com
}

Roads may have an important negative effect on animal dispersal rate and mortality and thus the functioning of local populations. However, road verges may be surrogate habitats for invertebrates. This creates a conservation dilemma around the impact of roads on invertebrates. Further, the effect of roads on invertebrates is much less understood than that on vertebrates. We studied the effect of roads on butterflies by surveying abundance, species richness and composition, and mortality in ten grassland patches along high-traffic roads ( 50-100 vehicles per hour) and ten reference grassland patches next to unpaved roads with very little traffic ( $<1$ vehicle per day) in southern Poland. Five 200-m transects parallel to the road were established in every grassland patch: at a road verge, $25 \mathrm{~m}$ from the verge, in the patch interior, and $25 \mathrm{~m}$ from the boundary between the grassland and field and at the grassland-arable field boundary. Moreover, one 200-m transect located on a road was established to collect roadkilled butterflies. The butterfly species richness but not abundance was slightly higher in grassland patches adjacent to roads than in reference grassland patches. Butterfly species composition in grasslands adjacent to roads differed from that in the reference patches. Proximity of a road increased variability in butterfly abundances within grassland patches. Grassland patches bordering roads had higher butterfly abundance and variation in species composition in some parts of the grassland patch than in other parts. These effects were not found in reference grassland patches, where butterfly species and abundance were more homogenously distributed in a patch. Plant species composition did not explain butterfly species. However, variance partitioning revealed that the presence of a road explained the highest proportion of variation in butterfly species composition, followed by plant species richness and abundance in grassland patches. Road mortality was low, and the number of roadkilled butterflies was less than $5 \%$ of that of all live butterflies. Nevertheless, the number and species composition of roadkilled butterflies were well explained by the butterfly 
communities living in road verges but not by total butterfly community structure in grassland patches. This study is the first to show that butterfly assemblages are altered by roads. These results indicate that (1) grassland patches located near roads are at least as good habitats for butterflies as reference grassland patches are, (2) roads create a gradient of local environmental conditions that increases variation in the abundance of certain species and perhaps increases total species richness in grassland patches located along roads, and (3) the impact of roads on butterflies is at least partially independent of the effect of plants on butterflies. Furthermore, (4) the direct impact of road mortality is probably spatially limited to butterflies living in close proximity to roads. 


\section{Roads affect the spatial structure of butterfly communities in grassland patches}

2

4

6 Kraków, Poland

7 tel: +48123703550 Australia

\section{Abstract}

Piotr Skórka ${ }^{1}$, Magdalena Lenda ${ }^{1,2}$, Dawid Moroń ${ }^{3}$

1. Institute of Nature Conservation, Polish Academy of Sciences, Mickiewicza 33, 31-120

e-mail: skorasp@gmail.com; pskorka@iop.krakow.pl

2 - School of Biological Sciences, The University of Queensland, Brisbane, Queensland,

3 - Institute of Systematics and Evolution of Animals, Polish Academy of Sciences, Sławkowska 17, 31-016 Kraków, Poland

Roads may have an important negative effect on animal dispersal rate and mortality and thus the functioning of local populations. However, road verges may be surrogate habitats for invertebrates. This creates a conservation dilemma around the impact of roads on invertebrates. Further, the effect of roads on invertebrates is much less understood than that on vertebrates. We studied the effect of roads on butterflies by surveying abundance, species richness and composition, and mortality in ten grassland patches along high-traffic roads $(\sim 50-100$ vehicles per hour) and ten reference grassland patches next to unpaved roads with very little traffic $(<1$ vehicle per day) in southern Poland. Five 200-m transects parallel to the road were established in every grassland patch: at a road verge, $25 \mathrm{~m}$ from the verge, in the patch interior, and $25 \mathrm{~m}$ from the boundary between the grassland and field and at the grassland-arable field boundary. Moreover, one 200-m transect located on a road was established to collect roadkilled butterflies. The butterfly species richness but not abundance was slightly higher in grassland patches adjacent to roads than in reference grassland patches. Butterfly species composition in grasslands adjacent to roads differed from that in the reference patches. Proximity of a road increased variability in butterfly abundances within grassland patches. Grassland patches bordering roads had higher butterfly abundance and variation in species composition in some parts of the 
33 grassland patch than in other parts. These effects were not found in reference grassland patches, 34 where butterfly species and abundance were more homogenously distributed in a patch. Plant 35 species composition did not explain butterfly species. However, variance partitioning revealed 36 that the presence of a road explained the highest proportion of variation in butterfly species 37 composition, followed by plant species richness and abundance in grassland patches. Road 38 mortality was low, and the number of roadkilled butterflies was less than $5 \%$ of that of all live 39 butterflies. Nevertheless, the number and species composition of roadkilled butterflies were well 40 explained by the butterfly communities living in road verges but not by total butterfly 41 community structure in grassland patches. This study is the first to show that butterfly 42 assemblages are altered by roads. These results indicate that (1) grassland patches located near 43 roads are at least as good habitats for butterflies as reference grassland patches are, (2) roads create a gradient of local environmental conditions that increases variation in the abundance of certain species and perhaps increases total species richness in grassland patches located along roads, and (3) the impact of roads on butterflies is at least partially independent of the effect of plants on butterflies. Furthermore, (4) the direct impact of road mortality is probably spatially limited to butterflies living in close proximity to roads. 
Introduction

Roads can exert severe impacts on animal populations (Benítez-López, Alkemade \& Verweij, 2010; Matos et al., 2017), either through direct road mortality (collisions with cars) or through habitat fragmentation and barrier effects increasing the isolation of populations (Trombulak \& Frissell, 2000; Forman et al., 2003; Tanner \& Perry, 2007; Schuster, Römer \& Germain, 2013). To date, most studies have focused on the estimates of road mortality, since millions of individuals from a wide range of taxonomic groups are being killed every year (Coelho, Kindel \& Coelho, 2008; Grilo, Bissonette \& Santos-Reis, 2009; Brzeziński, Eliava \& Żmihorski, 2012). However, roads also change the nearby environment by increasing influxes of salt and pollutants and changing the microclimate or water regime (Forman, 2000; Forman et al., 2003; Jackson \& Jobàggy, 2005; Green, Machin \& Cresser, 2006). These changes are especially well exhibited in the changes in plant communities near roads compared with changes in more distant habitats (Lee, Davies \& Power, 2012; Neher, Asmussen \& Lovell, 2013). Many herbivores are dependent on specific plants (Stam et al. 2013). Among insects, grassland butterflies are directly dependent on several plant species during different parts of their life cycle. Butterfly larvae usually have specific host-plant species/groups, while adults often use specific plant species as nectar sources (Munguira, Garcia-Barros \& Cano, 2009). As a result, a strong correlation between butterfly and plant species richness is often observed in grassland patches (Skórka et al., 2007; Chmura, Adamski \& Denisiuk, 2013). It may thus be expected that roads decrease the species richness and abundance of butterflies and plants and alter the species composition of the community in such a way that some species may tolerate adjacency while others avoid it. Moreover, alterations to plant communities, especially to host plants and nectar sources, by the creation or existence of

92 roads should also be indirectly related to grassland butterfly community structure, species

93 richness and abundance. However, roads may also change insect communities in a different

94 manner. Road verges, which are linear grassy structures accompanying roads, are regarded as a 
95 good surrogate habitat for plants and may act as their dispersal corridors (Tikka et al., 2001;

96 Kalwij, Milton \& McGeoch, 2008). This potential positive effect may, of course, be diminished

97 by road mortality, which can be high in butterflies (Skórka et al., 2015; Baxter-Gilbert et al.,

98 2015). However, it is unknown whether road mortality affects all butterflies in a grassland patch

99 adjacent to a road or is confined to the part of the grassland patch located directly along road

100 (e.g., the road verge). Therefore, the complexity of the possible direct and indirect effects that

101 roads can exert on butterflies make these insects especially interesting subjects to study in order

102 to understand the impacts of roads on insects at the community level. This is essential for

103 effective mitigation measures to minimize the impacts of existing and future roads on insect

104 populations, a subject that is rarely studied despite the important ecological roles that insects

105 play (Baxter-Gilbert et al., 2015; Munoz, Torres \& Gonzalez-Megias, 2015).

106 In this paper, we analyzed the effect of road proximity on plant and butterfly

107 communities, and we tested the following hypotheses (also see Table 1):

108 1. Grassland patches adjacent to roads with traffic have lower butterfly and plant species richness

109 and abundance/cover than grassland patches located far from roads

110 2. Grassland patches adjacent to roads with traffic have different butterfly and plant species

111 compositions than grassland patches located far from roads

112 3. Closer adjacency of roads increases variability in butterfly and plant richness, abundance and

113 species composition within grassland patches

114 4. Roads impose direct and indirect (via plants) effects on butterfly species composition in

115 grassland patches

116 5. Road mortality is explained by the abundance of all butterflies in the entire grassland patch

117 adjacent to the road

118

119

120 Study area and methods

121

122 Study areas

123 The study was conducted in grasslands in the vicinity of Kraków, Proszowice and Tarnów

124 (southern Poland). Grasslands are major habitats for European butterflies (Settele et al. 2009).

125 We selected 10 grassland patches adjacent to roads with heavy traffic (national and provincial

126 roads with $\sim 50-100$ vehicles per hour and one lane in each direction) and 10 reference (control) 
127 grassland patches located far (at least $200 \mathrm{~m}$ ) from major roads, with access via an unpaved field $128 \operatorname{road}(<1$ vehicle per day, Figure S1 in Supplemental File 1). The traffic on the studied paved roads was average for the traffic volume on Polish roads (Opoczynski 2016). Such roads constitute approximately 30\% ( $120000 \mathrm{~km})$ of the length of all roads in Poland (Opoczynski 131 2016).

132 The grassland patches were similar in size (7.8-13.5 hectares) and type (wet grassland 133 associated with Molinietalia type) The dominant plant species for this grassland type are the grasses Festuca pratensis, Deschampsia cespitosa, and Elymus repens and numerous flowering plants such as Cirsium arvense, Sanguisorba officinalis, Taraxacum officinale, Centaurea jacea, and Lythrum salicaria (Supplemental File 2).

We ensured that the two grassland types did not differ in their covers of arable fields $(t$ test: $t=0.578, d f=17.98, P=0.571$; mean $\pm S E: 62.6 \pm 2.6 \%$, range: $42-80 \%)$, woodland ( $t$-test, $t=-0.499, d f=17.94, P=0.624$; mean $\pm S E: 7.3 \pm 0.8 \%$, range: $2-12 \%)$, human settlements $(t-$ test, $t=-0.052, d f=17.60, P=0.958$; mean $\pm S E: 8.6 \pm 0.9 \%$, range: $3-15 \%)$ and other grasslands ( $t$-test, $t=-0.451, d f=17.99, P=0.657$; mean $\pm S E: 21.4 \pm 2.4 \%$, range: $6-42 \%)$ in a $500 \mathrm{~m}$ buffer around the boundary of each habitat patch. The studied grasslands were mown twice per year: once at the beginning of June and once in mid-August. This is a typical mowing scheme of grasslands in Poland. long, along which butterflies and plants were surveyed (Figure S1). The first transect was located at the verge (the border between the grassland and the road but not including asphalt). The second and third transects were located 25 meters from the edge of the road and in the patch interior. The fourth transect ran 25 meters from the border between the grassland patch and arable field. The fifth transect ran along the border between the grassland and cropland. The

152 purpose of this design was to test hypotheses 1-3 and to separate the effect of the road from the impact of the border itself. Changes in habitat conditions (soil and vegetation) occur in most areas to a distance of approximately 50 meters from the edge of the road (Forman \& Alexander, 155 1998).

The transects in reference grassland patches were identical to those in grassland patches adjacent to roads with traffic. In all reference grassland patches, there were unpaved field roads 
158 that allowed farmers to reach the area. However, these roads were grassy, and the number of

159 vehicles was less than one per day.

160

161 Butterfly and plant surveys

162 Butterflies were counted along transects during twelve surveys from mid-April to mid-

163 September in approximately 10-14 day intervals in 2013. European butterflies have different

164 developmental modes; some species are multivoltine (e.g., Araschnia levana), but there are also

165 species that only occur during a short period in a season (e.g., Callophrys rubi) (Settele et al.

166 2009). Consecutive transect counts were established to cover the entire flying period of butterfly

167 species with different biologies. The observer traveled the centerline of a $5 \mathrm{~m}$ wide transect.

168 Counts along transects (Pollard walks) is the standard and most commonly used method to study

169 populations of butterflies (Pollard \& Yates, 1993). Observations were carried out during good

170 weather (minimum temperature of $17^{\circ} \mathrm{C}$, wind up to $3^{\circ}$ on the Beaufort scale, and cloudy to $17125 \%)$.

172 During each visit, we also collected roadkilled butterflies along the $200 \mathrm{~m}$ part of the road 173 neighboring the studied grasslands (near both major roads and unpaved roads, but we did not

174 find any dead butterflies at the latter). These transects were adjacent to the transect located at the 175 road verge where living butterflies were counted (Figure S1).

176 Plants were surveyed in one $4 \times 10 \mathrm{~m}$ rectangular plot located in the middle of each

177 transect. Surveys were performed at the beginning of July. During the surveys, we noted the

178 coverage of each plant species (Mueller-Dombois \& Ellenberg 1974).

179 Field procedures were approved by the panel experts in the Ministry of Science and

180 Higher Education (approval: 0301/B/P01/2010/39). We received permission from farmers

181 (owners) of the land to conduct field surveys. Collecting butterflies on roads did not require any

182 formal permits because these were public roads.

183

184 Statistical analysis

185

186 Hypothesis 1. We used a generalized linear model (GLM) with a negative binomial error 187 structure and log-link function to test differences in butterfly and plant species richness, butterfly 188 abundance and plant cover between grassland patches adjacent to roads and reference grassland 
189 patches. In the case of butterflies, we calculated the sum of the individuals from five transects

190 located within a grassland patch to obtain proxies of total population sizes and because there was

191 little difference in butterfly abundance among the five transects within grassland patches (Rosin

192 et al., 2012; Skórka et al., 2013a). In addition, we also used an individual-based rarefaction

193 technique (Heck, van Belle \& Simberloff, 1975) to test the differences in butterfly species

194 number between grassland types while taking sampling effort into account. This analysis

195 calculated the expected number of species based on the number of individuals sampled. We did

196 not perform analyses for plants since we did not count individuals due to the difficulty in

197 defining what an individual plant is.

198

199

Hypothesis 2. We used partial RDA to test whether or not butterfly species composition and the abundance of each species differed between grassland patches adjacent to roads with traffic and reference grassland patches. We included the following covariates so that their effects were removed: transect location within a patch and plant richness and cover. Moreover, we performed partial redundancy analysis (partial RDA) using butterfly data summed across transects for every grassland patch. However, the results were similar enough that the conclusions were the same for either analysis. We used this method because the longest ordination axis in a detrended canonical correspondence analysis was short (1.4); thus, the linear method was preferred (Jongman, ter Braak \& van Tongeren, 1987).

In the case of plants, we used partial canonical correspondence analysis (partial CCA) to test whether or not plant species composition and mean cover differ between grassland patches adjacent to roads and reference grassland patches. We designated transect location as a variable to remove its effect. Plant cover was square root transformed before analysis.

We used 1000 Monte Carlo permutations to test the statistical significance of the

213 ordination axes.

215 Hypothesis 3. We used a generalized linear mixed model (GLMM) with a negative binomial 216 error structure and log-link function to test differences in butterfly and plant species richness, 217 butterfly abundance and plant cover between transect locations in different parts of the grassland 218 patches. Grassland patch identifier (site number) was assigned as a random effect. Analyses were conducted separately for grassland patches located near roads and reference ones. To determine 
220 which levels of the categorical factor (transect location) were significantly different, we used 221 paired contrast analysis.

222 We used partial RDA to test whether or not butterfly species composition and abundances 223 differ between transect locations in different parts of the grassland patches. Transect location was 224 treated as a categorical variable. We included the following covariates so that their effects were 225 removed: grassland patch identifier and combined plant richness and cover (first principal 226 component-PC1).

We used partial CCA to test whether or not plant species composition and cover differed between transect locations in different parts of the grassland patches. Transect location was treated as a categorical variable. We assigned patch identifier as a supplementary variable to remove its effect. Plant cover was square root transformed before analysis. We used 1000 Monte Carlo permutations to test the statistical significance of ordination axes and to determine which transect location contributed significantly to the differentiation of plant communities.

The partial RDA and partial CCA were calculated separately for grassland patches

234 adjacent to roads and reference ones.

Hypothesis 4. We performed variance partitioning analysis to test the relative contributions of (1) grassland type (adjacency of road or its absence), (2) plant diversity and (3) their joint effect to the differentiation of butterfly community composition. Plant diversity was represented by the plants ( $\mathrm{PC} 1$ explained $81 \%$ of variation between the two variables).

We used co-correspondence analysis (Co-CA) (ter Braak \& Schaffers, 2004) to reveal whether or not butterfly species composition and abundance can be explained by plant community composition. In this analysis, we used butterfly data summed and plant data averaged across the entire grassland patch because Co-CA currently does not allow for the effective removal of variation explained by covariates (ter Braak \& Schaffers, 2004).

Hypothesis 5. We used Co-CA to test the relationship between the butterfly community living in the grassland patch adjacent to roads and the species composition of roadkilled butterflies. Two Co-CA analyses were performed. First, we related the species composition of roadkilled 
251 patch to examine whether or not road mortality is associated with the butterfly community

252 measured across an entire grassland patch. Second, we related the abundance of roadkilled

253 butterflies to the abundances of live species in road verges. Given these two analyses, we could

254 infer whether or not the impact of road mortality is grassland wide or spatially limited to the road

255 verge. In addition to Co-CA, we used correlation analysis to seek a link between the total species

256 richness and abundance of living butterflies and the species richness and abundance of roadkilled

257 ones. Again, two sets of correlation analyses were performed: (1) one for living butterflies

258 summed across the entire grassland patch and (2) one for butterflies living on road verges only.

259 All GLMM, GLM and correlation analyses were performed in SPSS 23 software (IBM

260 Corp. 2015). All partial CCA, partial RDA and Co-CA analyses were performed in Canoco 5.0

261 software.

262

263 Results

264 Altogether, 14017 individuals belonging to 42 butterfly species were recorded during the study.

265 A total of 6922 individuals belonging to 42 butterfly species were recorded in patches adjacent

266 to roads, while 7095 individuals belonging to 38 species were recorded in reference grassland

267 patches (Table S1). In both grassland types, the dominant species ( $>5 \%$ of all individuals) were

268 Pieris rapae (1 635 individuals), Coenonympha pamphilus (1 472), Aphantopus hyperantus

269 (963), Gonepteryx rhamni (949), Polyommatus icarus (869), and Inachis io (746). Species that

270 occurred only in grassland patches adjacent to roads with traffic were Callophrys rubi (57

271 individuals), Plebejus argyrognomon (20), Nymphalis antiopa (8), and Argynnis aglaja (5).

272

273 Hypothesis 1. In total, there were significantly more butterfly species in grassland patches

274 adjacent to roads with traffic than in reference grassland patches (GLM $F_{1,18}=5.545, P=0.034$,

275 Figure 1a) after controlling for plant richness and cover (PC1plant; $\left.F_{1,17}=1.327, P=0.265\right)$.

276 There were no differences in mean butterfly abundance (GLM $F_{1,17}=0.133, P=0.720$, Figure

277 1b) between the two grassland types, but the abundance was marginally positively correlated

278 with plant species and cover (PC1plant; GLM $\left.F_{1,17}=4.397, P=0.051\right)$. Additionally, rarefaction

279 analysis revealed that the estimated number of butterfly species was higher in grassland patches

280 located near roads than in reference grasslands (Figure S2). 
There were no differences in total plant species richness $\left(\mathrm{GLM} F_{1,18}=2.985, P=0.101\right.$,

282 Figure $1 \mathrm{c})$ nor in mean cover $\left(\mathrm{GLM} F_{1,18}=2.340, P=0.144\right.$, Figure $\left.1 \mathrm{~d}\right)$ between grassland

283 patches located near roads and those located away from roads.

284

285 Hypothesis 2. Partial RDA showed that the butterfly communities significantly differed between

286

287

288

289

290

291

292

293

294

295

296

297

298

299

300

301

302

303

304

305

306

307

308

309

310

311

grassland patches located near roads with traffic and reference patches $(F=6.1, P=0.0005$,

Figure 2). The two grassland types accounted for $15.4 \%$ of the variation in species composition (Figure 2).

The partial CCA revealed that plant communities did not differ $(F=0.8, P=0.801)$

between grassland patches located near roads with traffic and reference ones (Figure 2).

Hypothesis 3. In grassland patches adjacent to roads with heavy traffic, there were no differences in butterfly species richness among the five transects located at different distances from a road (GLMM, $F_{4,45}=1.394, P=0.251$, Figure 3$)$. However, the mean abundance of butterflies varied depending on the location of the transect within the grassland patch $\left(\mathrm{GLMM}, F_{4,45}=3.440, P=\right.$ 0.015, Figure 3). Contrast analysis revealed that abundance was significantly higher in transects located inside grassland patches and $25 \mathrm{~m}$ from road verges than in transects at the field boundary (Figure 3).

Partial RDA showed that the location of a transect explained a significant $(F=2.0, P=$ $0.0005)$ amount $(18.4 \%)$ of the variation in butterfly species composition within grassland patches adjacent to roads with traffic (Figure 4). The first ordination axis separated butterfly communities along transects near grassland patch boundaries from butterfly communities along transects located inside the grassland patch (Figure 4). The second ordination axis mostly separated butterfly communities along transects near field boundaries from the butterfly communities along the transects at road verges (Figure 4). Accordingly, the tests indicated that transects located inside habitat patches $(F=3.0, P=0.0005)$, at road verges $(F=2.3, P=0.01)$ and at field boundaries $(F=2.0, P=0.0167)$ contributed significantly to the differentiation of butterfly communities within grassland patches adjacent to roads with traffic (Figure 4).

In the reference grassland patches, there were no differences in butterfly species richness $\left(\right.$ GLMM $, F_{4,45}=0.142, P=0.966$, Figure 3$)$ nor in mean abundance $\left(\right.$ GLMM $F_{4,45}=1.476, P=$ 0.225 , Figure 3 ) among the five transects located in different parts of the patch. 
The first two axes of partial RDA showed that the location of transects within the patches

313 explained $11.7 \%$ of the variation in butterfly species composition in reference grasslands (Figure

314 4). The ordination axes were statistically significant (test of all axes, $F=1.5, P=0.0345$ ). The

315 first ordination axis separated butterfly community transects located $25 \mathrm{~m}$ from field boundaries

316 from the other four transects $(\mathrm{F}=2.6, \mathrm{P}=0.04)$.

317 In grassland patches adjacent to roads with traffic, there were no differences in plant 318 species richness (GLMM, $F_{4,45}=2.359, P=0.068$, Figure S3). However, mean plant species

319 cover varied depending on the location within the patch $\left(\mathrm{GLMM}, F_{4,45}=3.190, P=0.022\right.$,

320 Figure S3). Contrast analysis revealed that cover was statistically higher at road verges than in

321 any other part of the grassland patch except the patch interior (Figure S3).

322 The first two axes of the partial CCA explained 10.1\% of the variation in plant species

323 composition (pseudo $F=1.4, P=0.0005$ ), and the location of transects within the patch

324 explained $13.7 \%$ of this variation (Figure S4). The first ordination axis separated plant

325 communities along transects located in road verges and $25 \mathrm{~m}$ from the road verge from plant

326 communities along transects located inside the habitat patch (Figure S4). The second ordination

327 axis separated plant communities along transects located at the field boundary and $25 \mathrm{~m}$ from

328 road verges from those recorded along other transects within grassland patches (Figure S4).

329 However, tests of the contribution of transect locations to the ordination indicated that only

330 transects located in road verges $(F=2.6, P=0.0025)$ and $25 \mathrm{~m}$ from road verges $(F=1.5, P=$

$3310.0187)$ significantly differentiated plant communities within grassland patches adjacent to roads

332 with traffic.

333 In the reference grassland patches, there were no differences in plant species richness

$334\left(\mathrm{GLMM}, F_{4,45}=0.274, P=0.893\right.$, Figure S3) and mean plant species cover between transect

335 locations $\left(\mathrm{GLMM} F_{4,45}=0.483, P=0.748\right.$, Figure S3).

336 The first two axes of the partial CCA explained 5.9\% of the variation in plant species

337 composition in reference grasslands. The location of transects within the patch explained $9.7 \%$ of

338 this variation (Figure S4). However, no ordination axis was statistically significant (test of all

339 axes, $F=1.0, P=0.6217)$, and transect location within the grassland patch was a nonsignificant

340 variable. 
342 Hypothesis 4. Overall, the Co-CA indicated that the plant community (total inertia $=7.162$ ) does

343 not explain butterfly species composition (total inertia $=0.91$ ): the two Co-CA axes explained 28

$344 \%$ of the variation in butterfly community composition, but the test of the first ordination axis

345 was statistically nonsignificant (lambda $=0.0093, P=0.128$ ), nor was the test of both ordination

346 axes (trace $=0.067, P=0.238$ ). The species richness of butterflies was correlated with plant

347 species richness ( $r=0.234, P=0.0189, n=$ data from all 100 transects) but not with plant cover

$348(r=0.171, P=0.0898, n=100)$. The same was true for butterfly abundance, which was

349 correlated with plant species richness $(r=0.347, P=0.0004, n=100)$ but not with plant cover $(r$

$350=0.075, P=0.456, n=100)$.

351

352

Hierarchical partitioning showed that $61 \%(F=5.8, P=0.0005)$ of the variation in

353

butterfly species composition was explained by grassland type, $37 \%(F=1.6, P=0.001)$ by

354

plant data (PC1 calculated from species richness and abundance), and $2 \%$ by their joint effect ( $F$

355

$=2.2, P=0.0005)$.

356

357

Hypothesis 5. Altogether, we recorded 154 roadkilled (2.2\% of all live) butterflies in grassland

patches adjacent to roads. Co-CA showed that the total community composition of alive butterflies (total inertia $=0.1598$ ) accounted for $47.4 \%$ of the variation in species composition of roadkilled butterflies (total inertia $=1.0197)$. However, the first ordination axis was statistically nonsignificant (lambda $=0.0147, P=0.0839)$, as were both ordination axes $($ trace $=0.0478, P=$ 0.305). We did not find any significant correlation between the number of roadkilled butterflies and the number of butterflies living in grassland patches neighboring roads $(r=0.185, P=0.608$, $364 n=10$; Figure S5).

However, in another Co-CA, we found that $48.3 \%$ of the variation in the species composition of roadkilled butterflies (total inertia $=2.737$ ) was explained by the species composition of butterflies living in road verges $(n=1444$ individuals, total inertia $=0.676$, Figure S6). The first ordination axis was statistically significant (lambda $=0.0636, P=0.0260)$ in this analysis. Additionally, there was a statistically significant correlation $(r=0.685, P=$ $0.029, n=10$ ) between the number of roadkilled butterflies and the number of butterflies living in the verges of grassland patches adjacent to roads with traffic (Figure 5). 
373 Discussion

374 Many studies have found a negative impact of roads on insects (see review in Munoz, Torres \&

375 Gonzalez-Megias, 2015). The influx of pollution may change soil properties and thus conditions

376 for plants that are food resources for adult butterflies and their larvae (Munguira, Garcia-Barros

377 \& Cano, 2009; Munguira \& Thomas, 1992), and road traffic may negatively affect population

378 size (Baxter-Gilbert et al., 2015; Munoz, Torres \& Gonzalez-Megias, 2015).

379 Our study revealed that roads had a subtle effect on butterfly communities. Contrary to the stated

380 hypothesis, grassland patches neighboring roads did not have lower butterfly richness nor

381 abundance compared to grassland patches located farther from roads. This pattern was consistent

382 after accounting for sampling effort (number of sampled individuals), as indicated by the

383 rarefaction analysis. This important finding may be an indication that roads with medium traffic

384 in Poland may have no direct negative impact on butterfly populations. The difference in species

385 richness between the two grassland types was small (in total, grassland patches adjacent to roads

386 had four species more than grassland patches located far from roads). Butterflies interact with

387 many other species and are plant pollinators. For example, field studies (Bakowski \& Boron,

388 2005; Bakowski et al., 2010; Ezzeddine \& Matter, 2008) found that one butterfly species visited

$3892-19$ plant species (mean $\pm S E=8.5 \pm 1.6$ plant species visited, $n=12$ butterfly species). In a

390 book on British butterflies, Dennis (2010) reported that one butterfly species utilized $54 \pm 7.5$

391 plant species on average (range: 2-232 plant species, $n=60$ butterfly species). Thus, each new

392 butterfly species introduces a number of interactions among different species, and differences in

393 butterfly species abundance between grassland types may indicate altered plant-butterfly

394 interactions in grassland patches adjacent to roads compared to patches more distant from roads.

395

396 The explanation of the high species richness and altered species composition in grassland

397 patches adjacent to roads is that they could be less isolated than reference grassland patches.

398 Reference grassland patches were surrounded by arable fields, and this land cover is usually an

399 inhospitable matrix that increases isolation (Luoto et al., 2003; Lenda \& Skórka, 2010; Öckinger

400 et al., 2012). As opposed to reference grasslands, patches located next to roads are connected

401 with other grasslands adjacent to roads via road verges. These marginal habitats may improve

402 species turnover among grasslands located near roads or even be a species pool for butterflies, 
403 enhancing patch colonization after some disturbances connected with grassland management

404 (Tikka et al., 2001; Brunzel et al., 2004; Moroń et al., 2017).

405 In earlier works, it was stated that road verges are often good habitats for butterflies (Ries,

406 Debinski \& Wieland, 2001; Wynhoff et al., 2011; Skórka et al., 2013a). Road verges have

407 specific conditions (higher influx of salt, higher temperatures, and altered water level) that may

408 allow certain butterflies, including species of conservation concern (e.g., Phengaris teleius and

409 P. nausithous), to survive in road verges, even in intensive agricultural landscapes (Wynhoff et

410 al., 2011). In our study, verges were an integral part of grassland patches. However, butterfly

411 species composition and abundances in verges were different from those inside grassland patches

412 and at the boundaries with arable fields (hypothesis 3, Table 1). Thus, the presence of roads

413 probably creates an environmental gradient within a grassland patch that may be preferred by

414 different species. This possible gradient may be related to higher plant cover or other factors (soil

415 chemistry, microclimate, etc.) at verges that were not investigated in this study. The presence of

416 gradients of conditions may increase available niches and boost species diversity (Amarasekare,

417 2003; Nord \& Forslund, 2015). This may also add to the explanation of the overall high butterfly

418 species richness in grassland patches adjacent to roads.

419 The boundary of a habitat patch has an important effect on the species composition in the

420 patch (Skórka et al., 2013b). Butterflies may respond strongly to even subtle habitat boundaries,

421 but those responses may be modified by the edge structure and local environmental conditions

422 (Ries \& Debinski, 2001). In our study, both studied boundaries-with roads and with arable

423 fields-had different species compositions and were dominated by different butterfly species, as

424 indicated by redundancy analysis. This finding also supports hypothesis 3 (Table 1), which states

425 that the adjacency of a road increases the variation in butterfly species diversity in different parts

426 of a grassland patch. It is noteworthy that in our study, the effect was visible in terms of species

427 composition but not in terms of total species abundance and richness. Earlier theoretical and

428 empirical works indicated that different species respond in various ways (in terms of the spatial

429 pattern of abundance) to habitat boundaries (Ries \& Debinski, 2001). This may be a result of

430 different boundary and matrix types (road and arable field) and different permeabilities of these

431 land covers (Skórka et al., 2013b; Kajzer-Bonk et al., 2016). In reference grassland patches, the

432 species composition at the boundary with a field road was similar to the species composition at

433 the boundary with an arable field. Field roads are very different from asphalt roads. The former 
434 are narrow, mostly covered by grass and often managed in the same way as neighboring

435 grassland. Thus, it is possible that field roads neighboring grasslands are perceived by butterflies 436 no differently than adjacent habitats are.

437 Several species showed preferences toward living in the part of grassland patches close to 438 road verges. These are usually small-bodied species such as Callophrys rubi, Plebeius 439 argyrognomon and Polyommatus coridon and very mobile, common species such as Issoria 440 lathonia and Papilio machaon. Interestingly, road verges had high abundances of species of 441 conservation concern such as Phengaris nausithous. This species is known especially for 442 surviving at road verges in intensively managed agricultural landscapes (Wynhoff et al., 2011). 443 This pattern may also result from the fact that road verges may be good habitat for ants (Itzhak, 444 2008; Wynhoff et al., 2011) and enhance their dispersal (DeMers, 1993). Ants are hosts for 445 larvae of these small blue butterflies. However, it should be noted that these small-bodied species 446 may be more susceptible to collision with vehicles than larger butterfly species are. Small insects 447 may fly over the asphalt at a low altitude while crossing the road (Soluk et al., 2011; Skórka et 448 al., 2013a) and thus may be susceptible to deadly collision with vehicles. Larger species, on the 449 other hand, often cross roads at a higher speed and at a higher altitude, mainly above the height 450 of passing cars (Skórka et al., 2013a).

451 Interestingly, the overall plant species richness and composition were not affected by 452 roads (hypotheses 1, 2 and 3, Table 1). However, the pattern of plant cover was very similar to 453 the pattern found for the abundance of butterflies. Butterflies are herbivores, and many of them 454 depend on specific plants during different life stages (Kitahara, Yumoto \& Kobayashi, 2008; 455 Dennis, 2010). Our co-correspondence analysis did not confirm the dependency of butterfly 456 species composition on plants (hypothesis 4, Table 1). This may result from the fact that adult 457 butterflies usually utilize several plant species as nectar sources, leading to the possibility of high 458 overlap among butterfly species using various plant species (Dennis, 2010). The latter possibility 459 seems to be confirmed by the high correlation between butterfly and plant species richness.

460 Nevertheless, the direct effect of roads on the butterfly community remained after controlling for 461 the effects of plant species richness and abundance, and this indicates that roads also modify 462 insect herbivore community composition in a different manner. This may be a direct effect of 463 road mortality, alteration to species behavior near roads and changes in microclimate conditions 464 at roads (Jackson \& Jobàggy 2005; Green, Machin \& Cresser, 2006; Skórka et al. 2013b). 
Road mortality accounted for less than 5\% of all butterflies recorded in grassland patches

466

467

468

469

470

471

472

473

474

475

476

477

478

479

480

481

482

483

484

485

486

487

488

489

490

491

492

493

494

495 near roads with traffic. Contrary to our expectations (hypothesis 5, Table 1), we showed that butterflies prone to being roadkilled were the same species that were common in the verges. Among the 34 roadkilled species, two (Phengaris teleius and P. nausithous) were endangered species, protected under Polish law. However, we found only 3 and 5 individuals of $P$. teleius and $P$. nausithous, which is $23 \%$ and $14 \%$ of all individuals recorded in transects in road verges and $5 \%$ and $4 \%$ of all individuals of these species in all transects within grassland patches adjacent to roads with traffic, respectively. Even if we assume imperfect detection of roadkilled butterflies (Skórka, 2016), this is still a relatively low level. It would be desirable to test the effect of roads with a higher traffic level (e.g., highways) than that in this study on butterflies. Highways are being developed in Europe; thus, an assessment of their impact on butterfly communities should be addressed in further studies. However, roads with average and low traffic are the most densely distributed in Polish landscapes and possibly have the most spatially widespread environmental impact (Kotlarek, 2007; Skórka et al., 2015).

Our study has certain limitations. With only one survey during the growing season, the measurements of plant coverage are just a snapshot in time and may not be an accurate reflection of the coverage of each species across the growing season. However, it should also be noted that in our earlier studies with repeated plant sampling, we found a strong positive correlation between the number of species and coverage recorded during consecutive counts. For example, in the study by Skórka et al. (2013a), the correlation coefficient between mid-May and mid-July plant surveys in road verges was $r=0.840(P<0.001, n=600$ plots $)$ for species richness and $r=$ $0.494(P<0.001, n=600)$ for plant coverage.

In our study, we also did not consider the survival, breeding success and larval development rate of the studied butterfly species in grassland patches. This limits our inference about the lack of a negative effect of roads on butterflies because grassland patches adjacent to roads may be ecological traps. A recent study indicated that road noise imposes stressful conditions on the development of monarch butterfly (Danaus plexippus) larvae in road verges of highways in North America (Davis et al., 2018). Moreover, the influx of road salt changes the properties of host plants and thereby impacts the larval development of butterflies, but the effect may be both positive and negative (Snell-Rood et al., 2014). In our studied grassland patches adjacent to roads, we observed courtship, oviposition and larval foraging. As these grassland 
496 patches are permanent, it is unlikely that the butterfly populations there were sustained by only

497 immigrants. The migration rate is usually low in butterfly populations and may increase genetic

498 variability rather than total population size (Nowicki \& Vrabec, 2011; Skórka et al., 2013b).

499 Moreover, our anecdotal observations in the studied grassland patches in following years

500 revealed that a high number of butterflies remained there. As the landscape compositions around

501 all the studied grassland patches were similar, we believe that the grassland patches adjacent to

502 roads were not ecological traps. Nevertheless, further studies should focus on comparing the

503 estimates of survival and reproductive success of butterflies inhabiting areas close to roads to

504 those of butterflies living in habitats not affected by roads.

505

506 Conclusions

507 Our results suggest that the proximity of a road has a specific spatial effect on butterfly

508 communities but little effect on plants. Butterfly communities were more spatially diversified

509 within a patch and species rich in grasslands located next to roads than in those far from roads.

510 Moreover, butterfly diversity was higher in grasslands neighboring roads than in grasslands far

511 from roads. This suggests that grasslands adjacent to roads with moderate traffic may be at least

512 as good habitats for butterflies as the grassland patches located far from roads are. Road

513 mortality was not very high and possibly predominantly affected individuals living on grassland

514 edges near roads, indicating that the entire patch is not equally affected by road traffic. Several

515 butterfly species have home ranges (do not move freely throughout the entire patch); thus, these

516 individuals occurring inside the patch may not be affected by roads even though the patch is

517 located next to the road. Additionally, potential mitigation actions (e.g., appropriate

518 management) may be focused on the part of the grassland located close to the road, not on the

519 entire patch. This may minimize the costs of the mitigation actions. Such actions would enhance

520 road verge habitats and would reduce road mortality. We propose to limit the mowing of road

521 verges in grassland patches because it was shown in a former study (Skórka et al., 2013a) that

522 limiting mowing increases the suitability of a verge as a habitat for butterflies and reduces their

523 collisions with cars.

524

525 Data Availability 
526 The following information was supplied regarding data availability: The raw data are provided in

527 Supplemental File 2.

528

529 References:

530 Amarasekare P. 2003. Competitive coexistence in spatially structured environments: A synthesis.

531 Ecology Letters 6, 1109-1122

532 Bakowski M, Boron M. 2005. Flower visitation patterns of some species of Lycaenidae

533 (Lepidoptera). Biological Letters 42:13-19.

534 Bakowski M, Filipiak A, Friz Z. 2010. Foraging behaviour and nectar use in adult Large Copper

535 Butterflies, Lycaena dispar (Lepidoptera: Lycarnidae). Entomologica Fennica 21:49-57.

536 Baxter-Gilbert JH, Riley JL, Neufeld CJH, Litzgus JD, Lesbarrères D. 2015. Road mortality

537 potentially responsible for billions of pollinating insect deaths annually. Journal of Insect

538 Conservation 19:1029-1035

539 Benítez-López A, Alkemade R, Verweij P. 2010. The impacts of roads and other infrastructure

540 on mammal and bird populations: A meta-analysis. Biological Conservation 143:1307-1316

541 Brzeziński M, Eliava G, Żmihorski M. 2012. Road mortality of pond-breeding amphibians

542 during spring migrations in the Mazurian Lakeland, NE Poland. European Journal of Wildlife

543 Research 58:685-693

544 Braak ter CJF, Schaffers AP. 2004. Co-Correspondence analysis: A new ordination method to

545 relate two community compositions. Ecology 85:834-846

546 Brunzel S, Elligsen H, Frankl R. 2004. Distribution of the Cinnabar moth Tyria jacobaeae L. at

547 landscape scale: use of linear landscape structures in egg laying on larval hostplant exposures.

$548 \quad$ Landscape Ecology 19:21-27.

549 Chmura D, Adamski P, Denisiuk Z. 2013. How do plant communities and flower visitors relate?

550 A case study of semi-natural xerothermic grasslands. Acta Societatis Botanicorum Poloniae

$55182: 99-105$

552 Coelho IP, Kindel A, Coelho AVP. 2008. Roadkills of vertebrate species on two highways

553 through the Atlantic Forest Biosphere Reserve, southern Brazil. European Journal of Wildlife

554 Research 54:689-699 
555 Davis AK, Schroeder H, Yeager I, Pearce J. 2018. Effects of simulated highway noise on heart

556 rates of larval monarch butterflies, Danaus plexippus: implications for roadside habitat

557 suitability. Biology Letters 14, 5,. pii: 20180018. doi: 10.1098/rsbl.2018.0018.

558 DeMers MN. 1993. Roadside ditches as corridors for range expansion of the western harvester

559 ant (Pogonomyrmex ccidentalis Cresson). Landscape Ecology 8:93-102

560 Dennis RLH. 2010. A resource-based habitat view for conservation. Butterflies in the British

561 landscape. Wiley-Blackwell, London

562 Ezzeddine M, Matter SF. 2008. Nectar flower use and electivity by butterflies in sub-alpine

563 meadows. Journal of the Lepidopterists' Society 62: 138-142

564 Forman RTT. 2000. Estimate of the area affected ecologically by the road system in the United

565 States. Conservation Biology 14:31-35

566 Forman RTT, Sperling D, Bissonette JA, Clevenger AP, Cutshall CD, Dale VH, Fahrig L,

567 France R, Goldman CR, Heanue K, Jones JA, Swanson FJ, Turrentine T, Winter TC. 2003.

568 Road Ecology: Science and Solutions. Washington, Covelo, London: Island Press.

569 Green SM, Machin R, Cresser MS. 2006. Effect of long-term changes in soil chemistry induced

570 by road salt applications on N-transformations in roadside solids. Environmental Pollution

$571 \quad 152: 20-31$

572 Grilo C, Bissonette JA, Santos-Reis M. 2009. Spatial-temporal patterns in Mediterranean

573 carnivore road casualties: Consequences for mitigation. Biological Conservation 142:301-313

574 Heck KL, Jr., van Belle G, Simberloff D. 1975. Explicit calculation of the rarefaction diversity

575 measurement and the determination of sufficient sample size. Ecology 56:1459-1461

576 IBM Corp. Released 2015. IBM SPSS Statistics for Windows, Version 23.0. Armonk, NY: IBM

577 Corp.

578 Itzhak MJJ. 2008. Seed harvester and scavenger ants along roadsides in Northern Israel. Zoology

579 in the Middle East 44:75-82

580 Jackson RB, Jobàggy EG. 2005. From icy roads to salty streams. Proceedings of the National

581 Academy of Sciences 102:14487-14488

582 Jongman RHG, ter Braak CJF, van Tongeren OFR. 1987. Data Analysis in Community and

583 Landscape Ecology. Pudoc, Wageningen, The Netherlands.

584 Kalwij J, Milton SJ, McGeoch MA. 2008. Road verges as invasion corridors? A spatial

585 hierarchical test in an arid ecosystem. Landscape Ecology 23:439-451 
586 Kitahara M, Yumoto M, Kobayashi T. 2008. Relationship of butterfly diversity with nectar plant 587 species richness in and around the Aokigahara primary woodland of Mount Fuji, central Japan. 588 Biodiversity and Conservation 17:2713-2734

589 Kotlarek Z. 2007. National Plan for the Road-Network Development 2007-2013.

$590 \quad$ http://www.gddkia.gov.pl

591 Lee MA, Davies L, Power SA. 2012. Effects of roads on adjacent plant community composition

592 and ecosystem function: an example from three calcareous ecosystems. Environmental

593 Pollution 163:273-280

594 Luoto M, Rekolainen S, Aakkula J, Pykälä J. 2003. Loss of plant species richness and habitat 595 connectivity in grasslands associated with agricultural change in Finland. AMBIO 32:447-452

596 Matos C, Petrovan S, Ward AI, Wheeler P. 2017. Facilitating permeability of landscapes

597 impacted by roads for protected amphibians: patterns of movement for the great crested newt.

598 PeerJ 5:e2922

599 Moroń D, Skórka P, Lenda M, Celary W, Tryjanowski P. 2017. Railway lines affect spatial 600 turnover of pollinator communities in an agricultural landscape. Diversity and Distributions

$601 \quad 23: 190-197$

602 Mueller-Dombois D, Ellenberg H. 1974. Aims and Methods of Vegetation Ecology. John Wiley $603 \&$ Sons, New York.

604 Munguira ML, Garcia-Barros E, Cano JM. 2009. Butterfly herbivory and larval ecology. In:

605 Ecology of butterflies in Europe: 43-45 (Settele J, Shreeve T, Konvicka M, Van Dyck H, Eds.). 606 Cambridge University Press, Cambridge.

607 Munguira ML, Thomas JA. 1992. Use of road verges by butterfly and burnet populations, and 608 the effect of roads on adult dispersal and mortality. Journal of Applied Ecology 29:316-329 609 Munoz PT, Torres FP, Gonzalez-Megias A. 2015. Effect of roads on insects: a review.

610 Biodiversity and Conservation 24:659-682

611 Neher DA, Asmussen D, Lovell ST. 2013. Roads in northern hardwood forests affect adjacent

612 plant communities and soil chemistry in proportion to the maintained roadside area. Science of 613 the Total Environment 449:320-327

614 Nord M, Forslund P. 2015. Environmental Gradients Explain Species Richness and Community 615 Composition of Coastal Breeding Birds in the Baltic Sea. PLoS ONE 10(2), e0118455 
616 Nowicki P, Vrabec V (2011) Evidence for positive density-dependent emigration in butterfly

617 metapopulations. Oecologia 167:657-665

618 Öckinger E, Bergman KO, Franzen M, Kadlec T, Krauss J, Kuussaari M, Pöyry J, Smith HG,

619 Steffan-Dewenter I, Bommarco R. 2012. The landscape matrix modifies the effect of habitat

620 fragmentation in grassland butterflies. Landscape Ecology 27:121-131

621 Opoczynski K. 2016. Synteza wyników GPR 2015 na zamiejskiej sieci dróg krajowych.

622 GDDKiA, Warszawa (www.gddkia.gov.pl)

623 Ries L, Debinski DM. 2001. Butterfly responses to habitat edges in the highly fragmented

624 prairies of Central Iowa. Journal of Animal Ecology 70:840-852

625 Ries L, Debinski DM, Wieland ML. 2001. Conservation value of roadside prairie restoration to

626 butterfly communities. Conservation Biology 15:401-411

627 Rosin Z, Myczko L, Skorka P, Lenda M, Moroń D, Sparks TH, Tryjanowski P. 2012. Butterfly

628 responses to environmental factors in fragmented calcareous grasslands. Journal of Insect

629 Conservation 16:321-329

630 Schuster R, Römer H, Germain RR. 2013. Using multi-scale distribution and movement effects

631 along a montane highway to identify optimal crossing locations for a large-bodied mammal

632 community. PeerJ 1:e189 https://doi.org/10.7717/peerj.189

633 Settele J, Shreeve T, Konvička M, Van Dyck H. 2009. Ecology of Butterflies in Europe.

634 Cambridge University Press

635 Skórka P. 2016. The detectability and persistence of road-killed butterflies: An experimental

636 study. Biological Conservation 200:36-43

637 Skórka P, Lenda M, Moroń D, Kalarus K, Tryjanowski P. 2013 a. Factors affecting road

638 mortality and the suitability of road verges for butterflies. Biological Conservation 159:148-157

639 Skórka P, Nowicki P, Lenda M, Witek M, Sliwinska EB, Settele J, Woyciechowski M. 2013 b.

640 Different flight behaviour of the endangered Scarce Large Blue butterfly Phengaris teleius

641 (Lepidoptera: Lycaenidae) within and outside its habitat patches. Landscape Ecology 28:533-

$642 \quad 546$

643 Skórka P, Lenda M, Moroń D, Martyka R, Tryjanowski P, Sutherland WJ. 2015. Biodiversity

644 collision blackspots in Poland: separation causality from stochasticity in roadkills of butterflies.

645 Biological Conservation 187:154-163 
646 Snell-Rood EC, Espeset A, Boser CJ, White WA, Smykalski R. 2014. Anthropogenic changes in 647 sodium affect neural and muscle development in butterflies. Proceedings of the National

648 Academy of Sciences of the United States of America 111:10221-10226

649 Spooner PG, Smallbone L. 2009. Effects of road age on the structure of roadsied vegetation in 650 south-eastern Australia. Agriculture, Ecosystems \& Environment 129:57-64

651 Stam JM, Kroes A, Li Y, Gols R, van Loon JJ, Poelman EH, Dicke M. 2013. Plant interactions

652 with multiple insect herbivores: from community to genes. Annual Review in Plant Biology

$653 \quad 65: 689-713$

654 Tanner D, Perry J. 2007. Road effects on abundance and fitness of Galápagos lava lizards

655 (Microlophus albemarlensis). Journal of Environmental Management 85:270-278

656 Tikka PM, Högmander H, Koski PS. 2001. Road and railway verges serve as dispersal corridors

657 for grassland plants. Landscape Ecology 16:659-666

658 Trombulak SC, Frissell C. 2000. Review of ecological effects of roads on terrestrial and aquatic

659 communities. Conservation Biology 14:18-30

660 Wobeser G, Wobeser A. 1992. Carcass disappearance and estimation of mortality in a simulated

661 die-off of small birds. Journal of Wildlife Diseases 28:548-554

662 Wynhoff I, Gestel R, van Swaay C, Langevelde F. 2011. Not only the butterflies: Managing ants 663 on road verges to benefit Phengaris (Maculinea) butterflies. Journal of Insect Conservation

664 15:189-206

665

666

667

668

669

670

671

672

673

674

675

676

677

678

679

680

681

682 
683

684

685

686

687

688

689

690

691

692

693

694

695

696

697

698

699

700

701

702

703

704

705

706

707

708

709

710

711

712

Figure captions

Figure 1. The impact of grassland location on the number of butterfly species and individuals

713 The impact of grassland type on the mean number of butterfly species (a) and individuals (c) and

714 the mean number of plant species (c) and cover (d) within grassland patches adjacent to roads

715 with traffic and those far from roads. Whiskers are 95\% confidence intervals. Note: * indicates a

716 statistically significant difference at $P<0.05$.

717

718 Figure 2. Differentiation of butterfly and plant species composition in grassland patches

719 adjacent to roads and those farm from roads

720 Ordination of butterfly $(\mathrm{a}, \mathrm{b})$ and plant $(\mathrm{c}, \mathrm{d})$ species in grassland patches adjacent to roads with

721 traffic and those far from roads. Partial redundancy (butterflies) and partial canonical

722 correspondence (plants) analyses were used for ordination of species after removing the effects 
723 of transect location within a patch. Road - grassland patches adjacent to roads; Reference -

724 grassland patches located far from roads. Species abbreviations are the first letters of the genus

725 and species names.

726

727 Figure 3. The impact of transect location within a grassland patch on the number of 728 butterfly species and individuals

729 The impact of transect location on the mean number of species (a, b) and individuals (c, d)

730 within grassland patches adjacent to roads with traffic (a, c) and those far from roads (b, d).

731 Whiskers are $95 \%$ confidence intervals. The only statistically significant differences were found

732 for the abundance of butterflies (c): locations with different capital letters are significantly

733 different.

Figure 4. Differentiation of butterfly species in different parts of the grassland patches adjacent to roads with traffic and these far from roads

Ordination of butterfly species in a partial redundancy analysis in different parts of the grassland patches adjacent to roads with traffic $(a, b)$ and far from a road (c, d). Road verge - transect on a road verge, $25 \mathrm{~m}$ from road verge - transect located inside a grassland patch $25 \mathrm{~m}$ from a road verge, inside - transect located in the interior of the grassland patch, $25 \mathrm{~m}$ from field boundary transect located inside the grassland patch $25 \mathrm{~m}$ from a border between the patch and arable field, and field boundary - transect located at the border between the grassland patch and arable field. In the case of reference grassland patches (grassland located far from a road), "road verge" was a transect located along a field road used by farmers. Species abbreviations are the first letters of the genus and species names. 


\section{Table 1 (on next page)}

Summary of major results and support for hypotheses 
1 Table 1. Summary of major results and support for hypotheses

\begin{tabular}{|c|c|c|c|c|c|}
\hline & Hypothesis & Explanations/Predictions & Statistical test & Support & Comments \\
\hline 1. & $\begin{array}{l}\text { Grassland patches adjacent to roads } \\
\text { with traffic have lower butterfly and } \\
\text { plant species richness and } \\
\text { abundance/cover than grassland patches } \\
\text { located far from roads }\end{array}$ & $\begin{array}{l}\text { Influxes of pollutants, salt and road } \\
\text { mortality potentially negatively } \\
\text { affect animal and plant populations. } \\
\text { Thus, presence of roads should } \\
\text { have negative effects on diversity } \\
\text { indices. }\end{array}$ & $\begin{array}{l}\text { Generalized linear models } \\
\text { with negative binomial } \\
\text { error variance }\end{array}$ & No & $\begin{array}{l}\text { Butterfly species richness was } \\
\text { higher in grassland patches } \\
\text { adjacent to roads than in grassland } \\
\text { patches located far from roads. No } \\
\text { differences were found in butterfly } \\
\text { abundance nor in plant species } \\
\text { richness and cover between two } \\
\text { types of grassland }\end{array}$ \\
\hline 2. & $\begin{array}{l}\text { Grassland patches adjacent to roads } \\
\text { with traffic have different butterfly and } \\
\text { plant species compositions than } \\
\text { grassland patches located far from } \\
\text { roads }\end{array}$ & $\begin{array}{l}\text { Roads change conditions in } \\
\text { adjacent grassland patches. Thus it } \\
\text { is expected that species } \\
\text { composition and species } \\
\text { abundances are different (but } \\
\text { without specifying the difference) } \\
\text { in grassland patches adjacent to } \\
\text { roads than in grassland patches } \\
\text { located far from roads. }\end{array}$ & $\begin{array}{l}\text { Partial redundancy } \\
\text { analysis (butterflies), } \\
\text { partial canonical } \\
\text { correspondence analysis } \\
\text { (plants) }\end{array}$ & Yes/No & $\begin{array}{l}\text { Species composition of butterflies } \\
\text { (but not plants) was different in } \\
\text { grassland patches adjacent to roads } \\
\text { than in grassland patches located } \\
\text { far from roads. }\end{array}$ \\
\hline 3. & $\begin{array}{l}\text { Closer adjacency of roads increases } \\
\text { variability in butterfly and plant } \\
\text { richness, abundance and species } \\
\text { composition within grassland patches }\end{array}$ & $\begin{array}{l}\text { Roads change environmental } \\
\text { conditions in areas adjacent to } \\
\text { roads. Thus, this should create } \\
\text { gradient of conditions from the road } \\
\text { verge towards habitat patch interior. } \\
\text { Hence, species richness, abundance } \\
\text { and composition should vary in } \\
\text { different parts of a grassland patch } \\
\text { adjacent to road. This should not be } \\
\text { visible in grassland patches located } \\
\text { far from roads. }\end{array}$ & $\begin{array}{l}\text { Generalized linear models } \\
\text { with negative binomial } \\
\text { error variance (species } \\
\text { richness and } \\
\text { abundance/cover), partial } \\
\text { redundancy analysis } \\
\text { (species composition of } \\
\text { butterflies), partial } \\
\text { canonical correspondence } \\
\text { analysis (plants) }\end{array}$ & Yes/No & $\begin{array}{l}\text { Butterfly and plant } \\
\text { abundance/cover and species } \\
\text { composition (but not species } \\
\text { richness) differed among transects } \\
\text { located in different parts of a } \\
\text { grassland patch adjacent to road. } \\
\text { This was not found in grassland } \\
\text { patches located far from roads. }\end{array}$ \\
\hline 4. & $\begin{array}{l}\text { Roads impose direct and indirect (via } \\
\text { plants) effects on butterfly species } \\
\text { composition in grassland patches }\end{array}$ & $\begin{array}{l}\text { Roads change conditions in } \\
\text { adjacent grassland patches that may } \\
\text { affect both butterflies and plants. } \\
\text { However, butterflies are herbivores } \\
\text { strongly dependent on plants. Thus, } \\
\text { species richness, abundance and } \\
\text { composition of butterflies in } \\
\text { grassland patches may be affected } \\
\text { directly by roads (e.g. road } \\
\text { mortality) and indirectly by plants } \\
\text { (e.g. species composition, cover). }\end{array}$ & $\begin{array}{l}\text { Co-correspondence } \\
\text { analysis, correlation } \\
\text { analysis, hierarchical } \\
\text { variance partitioning } \\
\text { (separating direct effect of } \\
\text { road adjacency on } \\
\text { butterfly species } \\
\text { composition from the } \\
\text { effect of plant species on } \\
\text { butterfly species } \\
\text { composition). }\end{array}$ & Yes/No & $\begin{array}{l}\text { Plant species composition did not } \\
\text { explain butterfly species } \\
\text { composition in grassland patches. } \\
\text { However, butterfly species } \\
\text { richness correlated with plant } \\
\text { species richness. In total both } \\
\text { adjacency of a road and plant } \\
\text { species richness and abundance } \\
\text { had significant individual impact } \\
\text { on butterfly species composition in } \\
\text { grassland patches. }\end{array}$ \\
\hline 5 & $\begin{array}{l}\text { Road mortality is explained by the } \\
\text { abundance of all butterflies in the entire }\end{array}$ & $\begin{array}{l}\text { Road mortality is one of the most } \\
\text { direct effects of roads on butterflies. }\end{array}$ & $\begin{array}{l}\text { Correlation analysis, co- } \\
\text { correspondence analysis. }\end{array}$ & No & $\begin{array}{l}\text { Butterfly species richness and } \\
\text { composition on road verges rather }\end{array}$ \\
\hline
\end{tabular}




\begin{tabular}{|c|c|c|}
\hline grassland patch adjacent to the road & $\begin{array}{l}\text { However, road mortality may affect } \\
\text { (1) entire species population in a } \\
\text { grassland patch adjacent to road or } \\
\text { (2) only part of the population } \\
\text { occurring near the road (e.g. on } \\
\text { road verge). Thus, if the first is true } \\
\text { the species richness, abundance and } \\
\text { composition of live butterflies in a } \\
\text { grassland patch explain the } \\
\text { composition and number of } \\
\text { roadkills. If road have spatially } \\
\text { limited impact then data on } \\
\text { butterflies on road verges explain } \\
\text { composition and number of } \\
\text { roadkills. }\end{array}$ & $\begin{array}{l}\text { than in entire grassland patch better } \\
\text { explained number and species } \\
\text { composition of roadkilled } \\
\text { butterflies. }\end{array}$ \\
\hline
\end{tabular}




\section{Figure 1}

The impact of grassland location on the number of butterfly species and individuals

The impact of grassland type on the mean number of butterfly species (a) and individuals (c) and the mean number of plant species (c) and cover (d) within grassland patches adjacent to roads with traffic and those far from roads. Whiskers are $95 \%$ confidence intervals. Note: * indicates a statistically significant difference at $P<0.05$. 


\section{Butterflies}

(a)

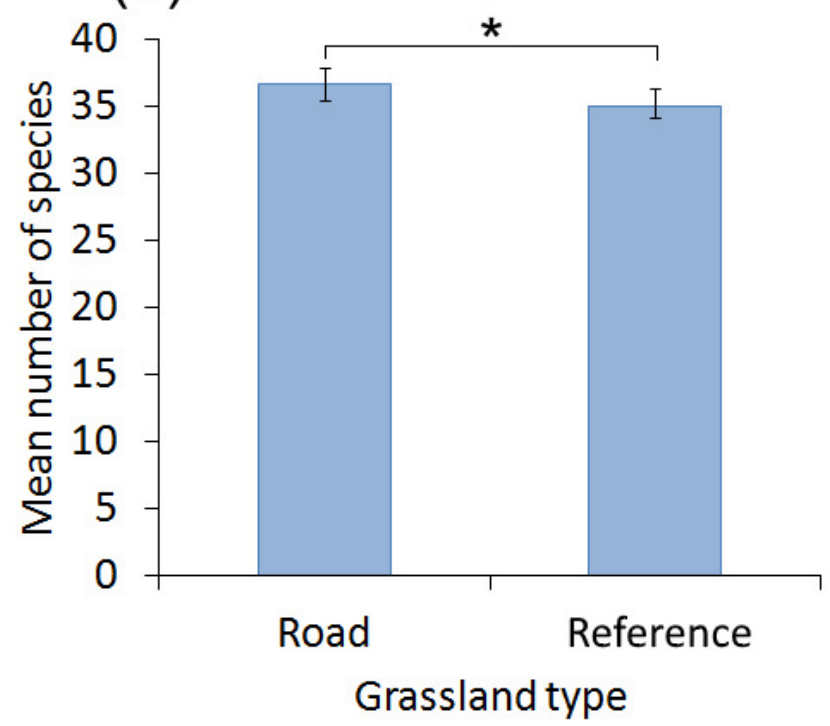

(b)

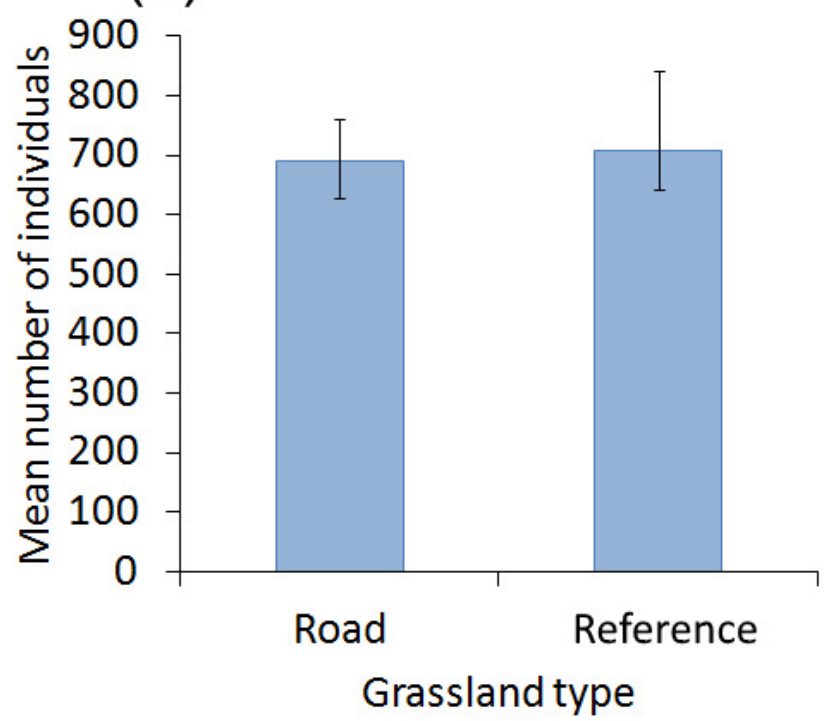

Plants

(c)

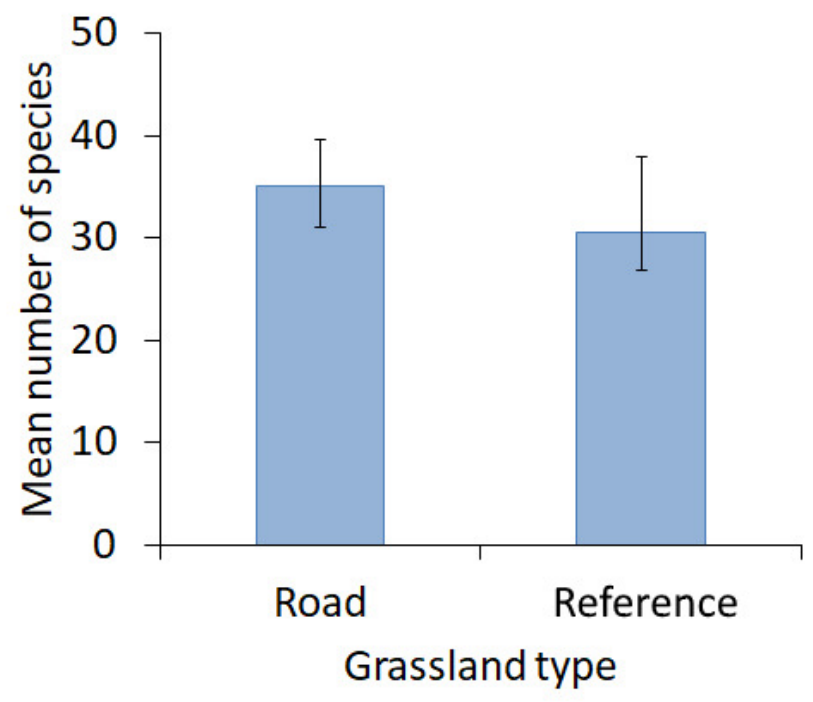

(d)

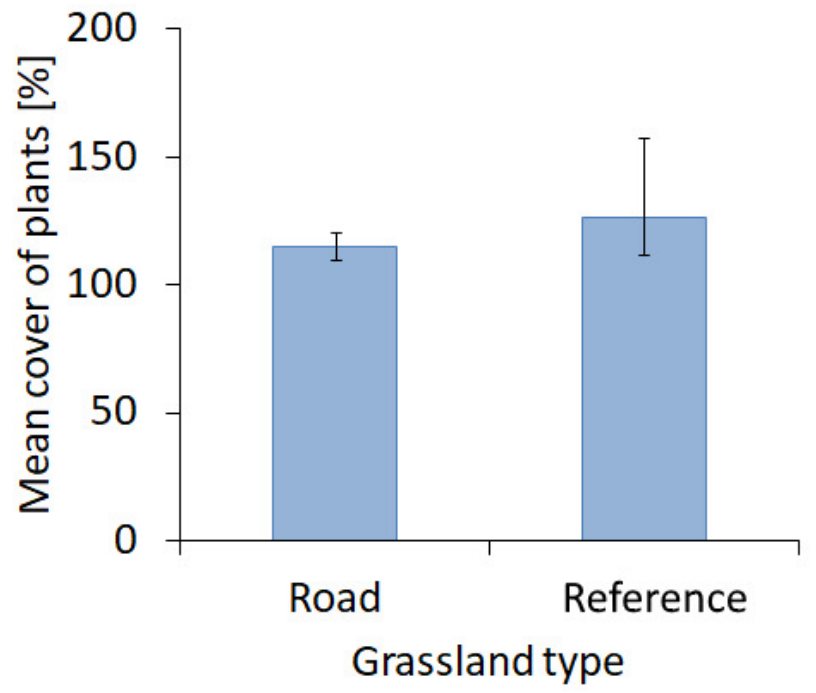




\section{Figure 2}

Differentiation of butterfly and plant species composition in grassland patches adjacent to roads and those farm from roads

Ordination of butterfly $(a, b)$ and plant $(c, d)$ species in grassland patches adjacent to roads with traffic and those far from roads. Partial redundancy (butterflies) and partial canonical correspondence (plants) analyses were used for ordination of species after removing the effects of transect location within a patch. Road - grassland patches adjacent to roads; Reference - grassland patches located far from roads. Species abbreviations are the first letters of the genus and species names. 
(a)

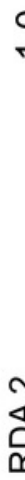

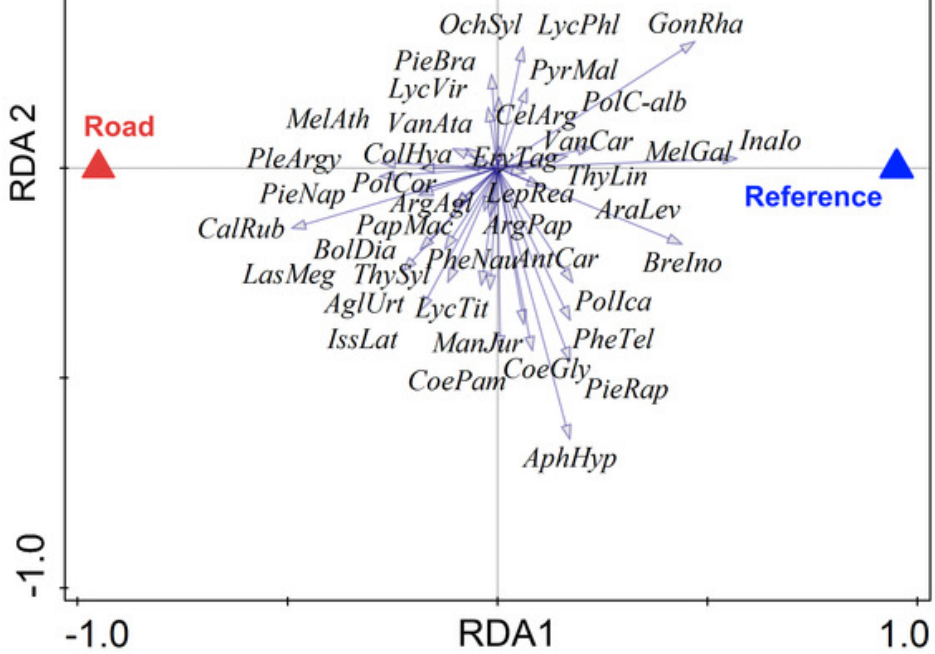

(c)

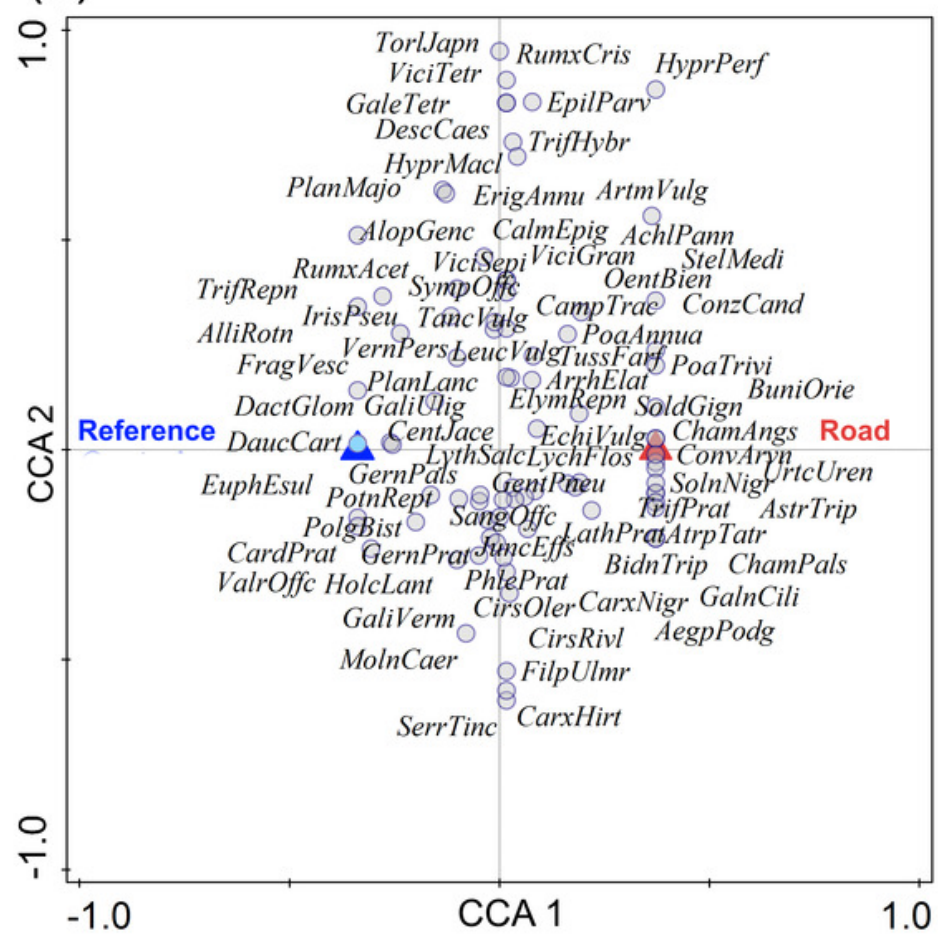

(b)

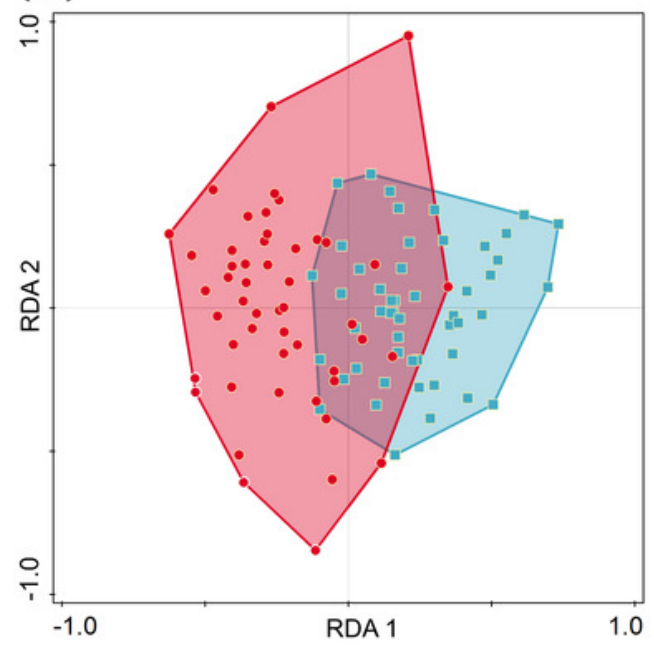

Legend:

- Road

- Reference (d)

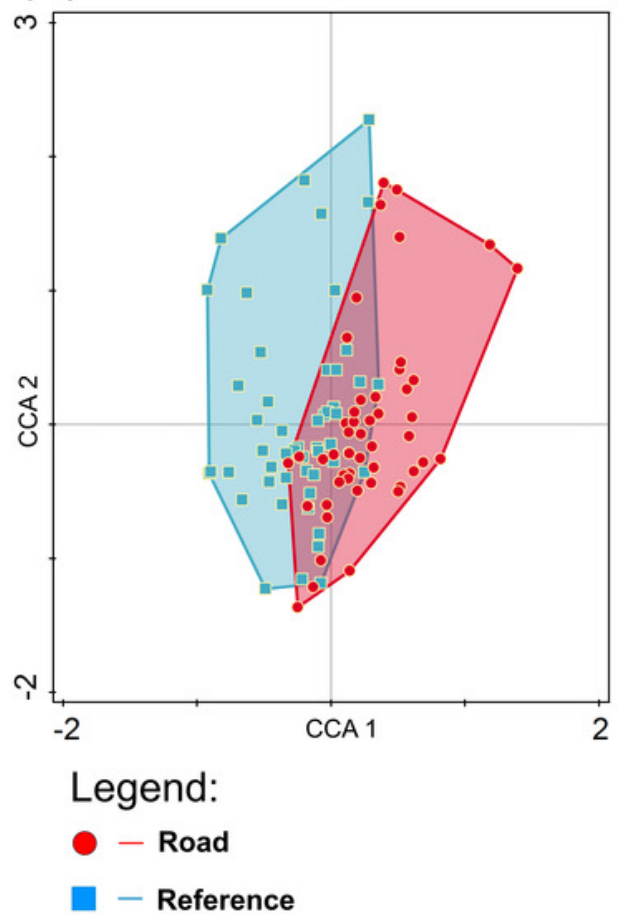


Figure 3

The impact of transect location within a grassland patch on the number of butterfly species and individuals

The impact of transect location on the mean number of species $(a, b)$ and individuals $(c, d)$ within grassland patches adjacent to roads with traffic $(a, c)$ and those far from roads $(b, d)$. Whiskers are $95 \%$ confidence intervals. The only statistically significant differences were found for the abundance of butterflies (c): locations with different capital letters are significantly different.

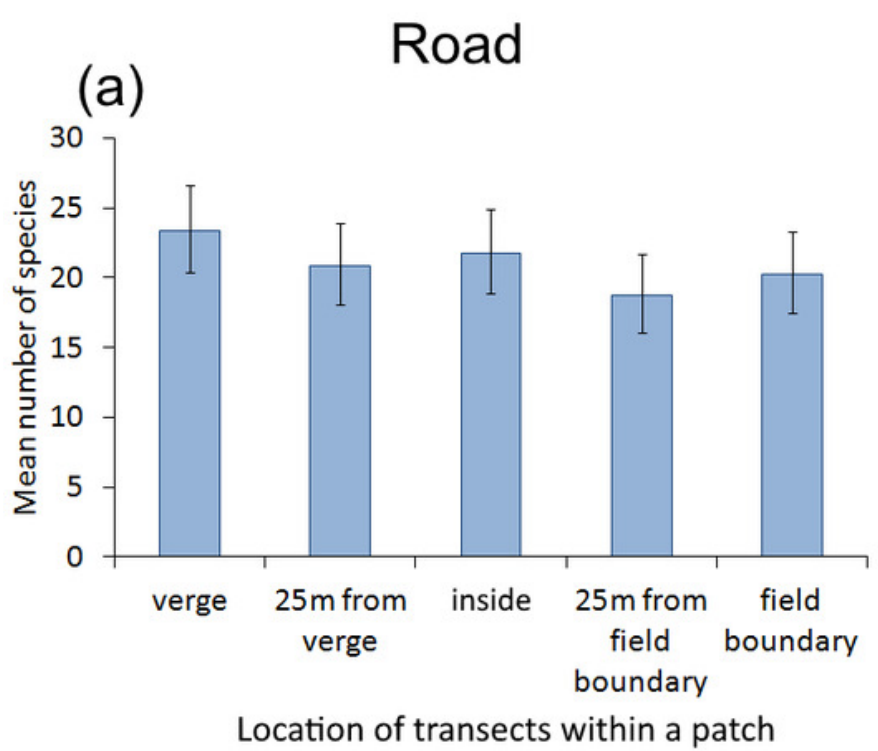

(c)

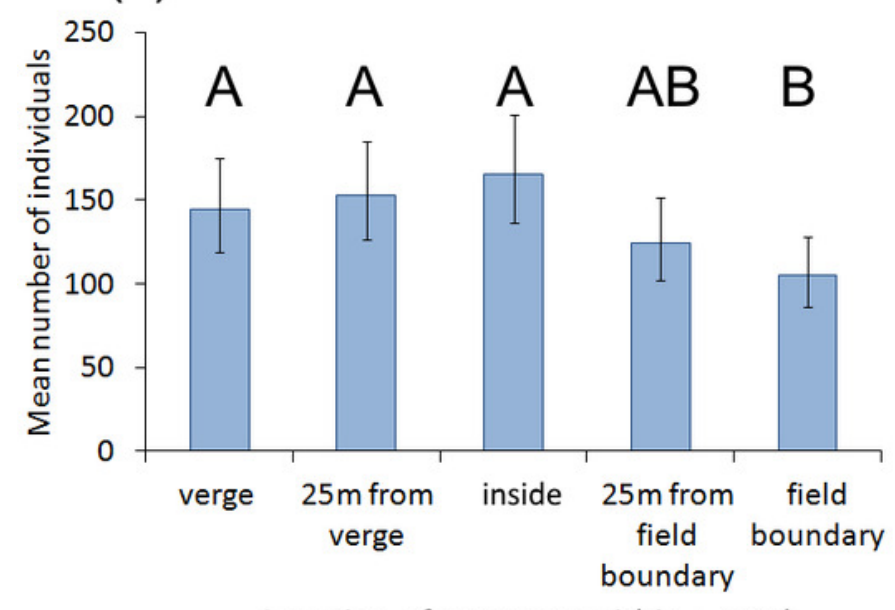

Location of transects within a patch (b)

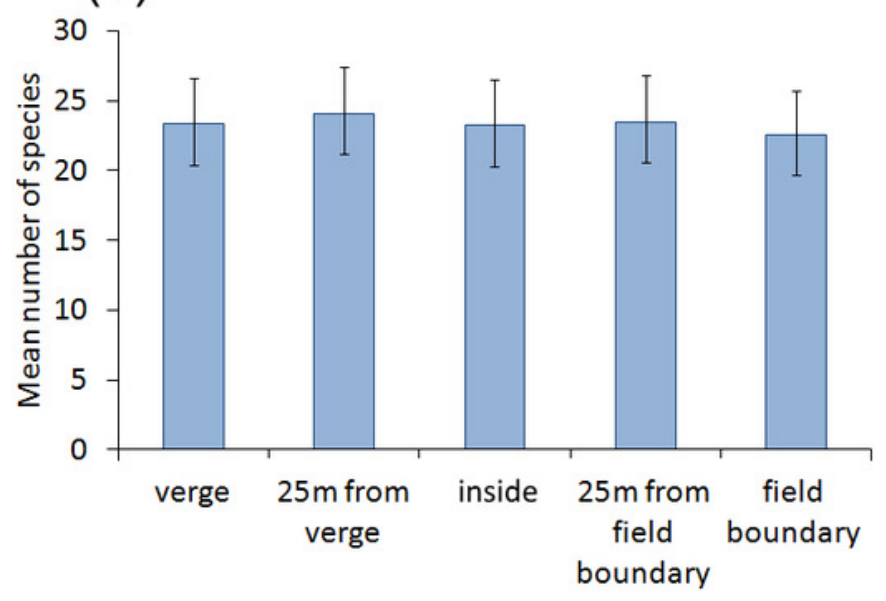

Location of transects within a patch

(d)

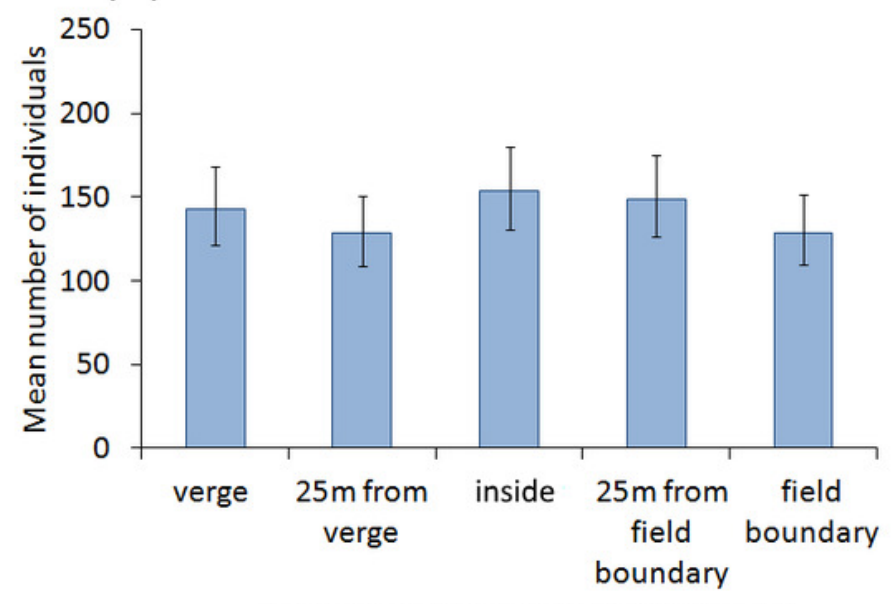

Location of transects within a patch 


\section{Figure 4}

Differentiation of butterfly species in different parts of the grassland patches adjacent to roads with traffic and these far from roads

Ordination of butterfly species in a partial redundancy analysis in different parts of the grassland patches adjacent to roads with traffic $(a, b)$ and far from a road (c, d). Road verge transect on a road verge, $25 \mathrm{~m}$ from road verge - transect located inside a grassland patch $25 \mathrm{~m}$ from a road verge, inside - transect located in the interior of the grassland patch, $25 \mathrm{~m}$ from field boundary - transect located inside the grassland patch $25 \mathrm{~m}$ from a border between the patch and arable field, and field boundary - transect located at the border between the grassland patch and arable field. In the case of reference grassland patches (grassland located far from a road), "road verge" was a transect located along a field road used by farmers. Species abbreviations are the first letters of the genus and species names. 
(a)

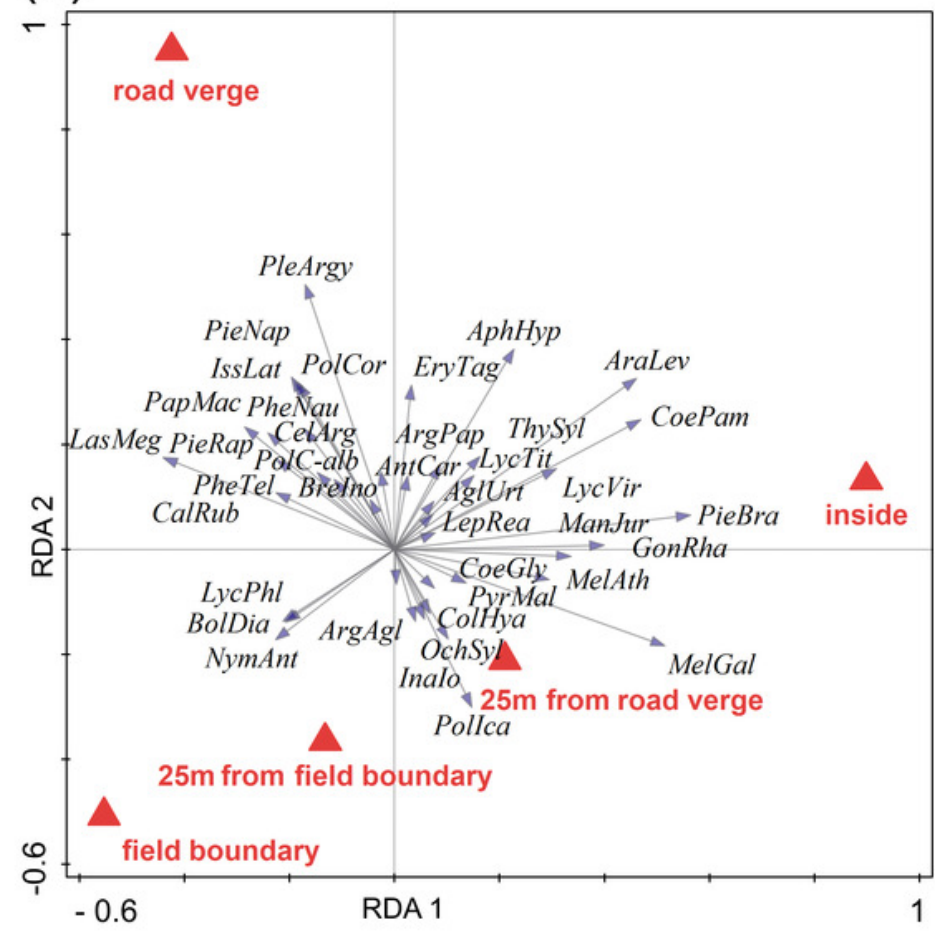

(c)

\section{Reference}

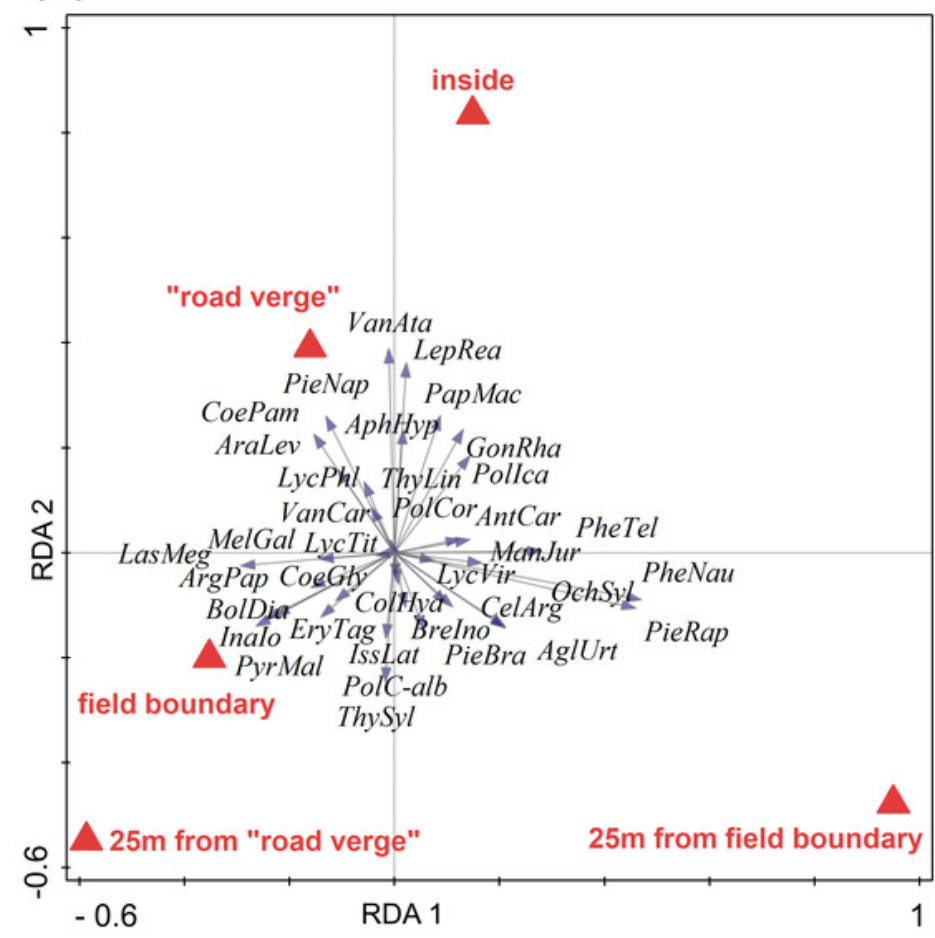

(b)

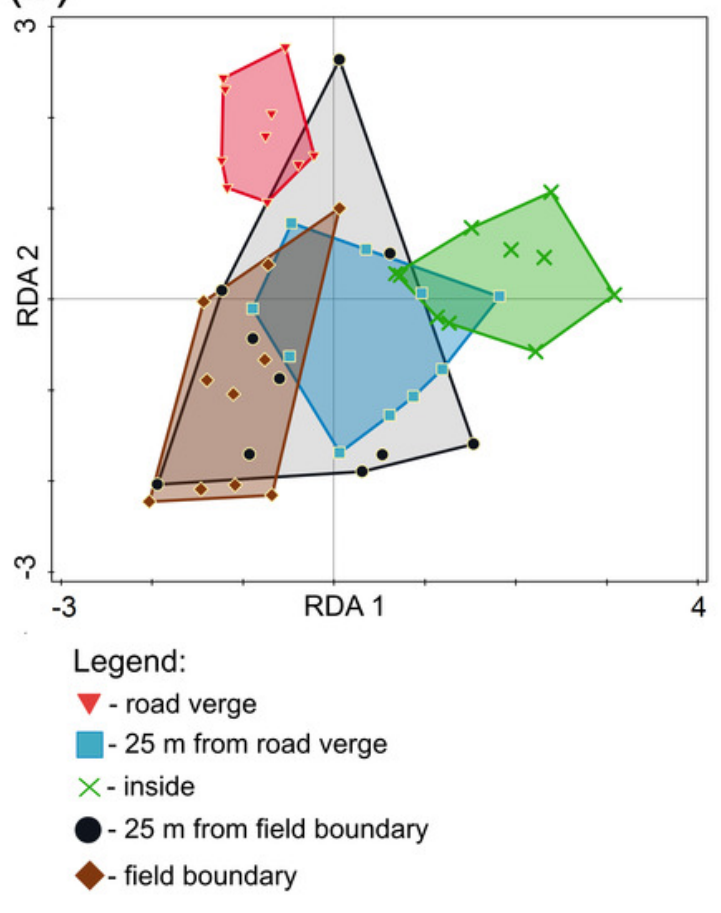

(d)

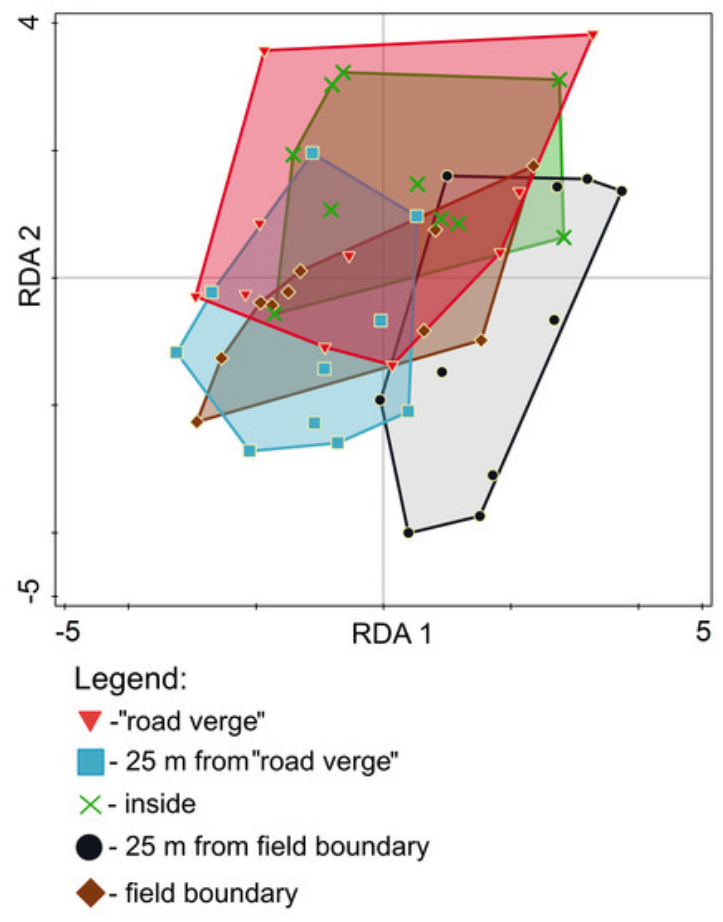


Figure 5

Correlation between the number of butterflies living in road verges and the number of roadkilled butterflies.

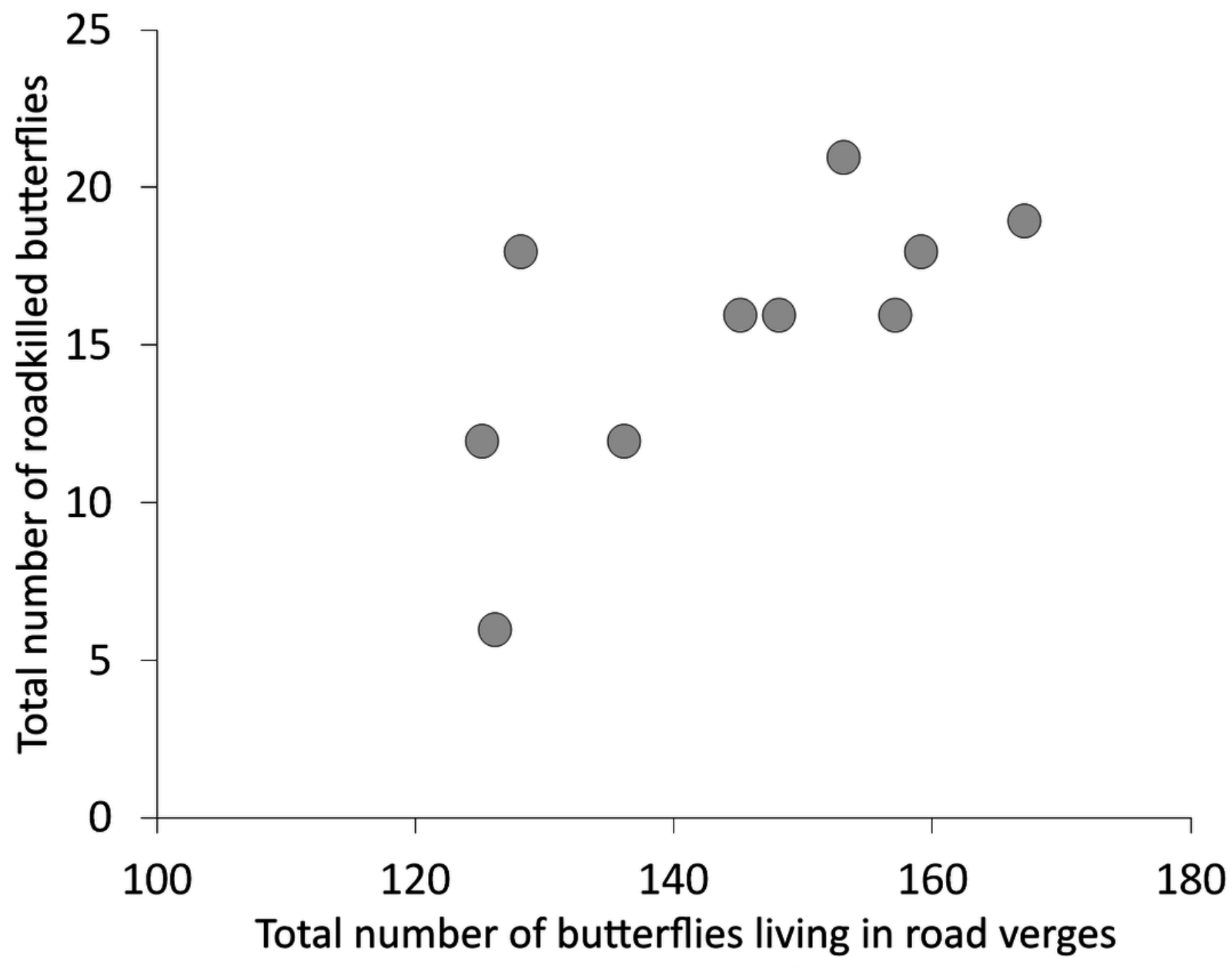

